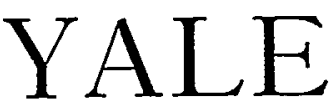

$\frac{\text { LAW JOUR N A L }}{\underline{\text { Vot II }}}$

\title{
PRACTICAL SUGGESTIONS TO STUDENTS AND YOUNG LAWYERS.
}

By Isaac Atwater, Ex-Associate Justice of the SUPREMe Court of Minnesota.

One of the most interesting and useful. lectures to which I listened while in attendance on the Yale Law School was given by the eminent Judge Storrs, near the close of his life, and was limited to words of practical advice on parting with his class. Perhaps most who read this paper may have received similar instruction. And yet the experience of no two men is the same, and perhaps that of one who has been actively engaged in the discharge of professional and judicial duties for more than forty years, may not be entirely without value to the young beginner.

A word, however, first, to those young men who are debating in their own minds whether to choose the law as a profession, and which if chosen, must be depended upon in after life for a livelihood. The immature age at which this question usually arises, precludes the possibility of giving advice in determining the question, which would be of material value, in any individual case. And yet there are some considerations not without weight in determining the question. And among the first of these is, that if a man chooses the profession of law, with the primary idea of using it as a means of acquiring wealth, he had better at once abandon the thought of entering the profession. For two reasons, viz: he will be likely, indeed, almost certain, to be disappointed, but what is worse, he will in all probability, use and degrade the noblest of professions to the most ignoble of purposes. For my 
own observation confirms the truth of the statement ascribed to Webster, that, "lawyers, as a rule, work hard, live well, and die poor." The exceptions to this are so few that they may be said to prove the rule.

And secondly he must have a natural taste for study, and habits of close application, for these are indispensably necessary, not only for admission to the bar, but for successful practice of the profession in all after life. If a young man has doubts as to the possession of these qualities, he might well hesitate as to choosing this profession, for without them, he can never attain eminence as a lawyer.

But assuming that the choice is made, the next important question is, how he shall best fit himself for admission to the bar. In regard to this, there can scarcely be a question but that two years spent in a first-class law school will afford the most thorough preparation. Not that this alone will fit the student to enter upon practice - a year or two more may be profitably spent in a law office having a large practice. But in no other way can the fundamental principles of law be so thoroughly acquired and fixed in the mind, and make themselves felt and recognized in practice through all future life. The experienced lawyer can, without long observation of the young man in the trial and argument of cases, almost certainly decide whether he has enjoyed the advantage here spoken of In all cases where it is possible the young man should not hesitate to avail himself of this advantage. The writer hereof had not a dollar nor any means on which to rely, when he entered the Yale school, but supported himself by teaching. Almost any one can do this (especially if a college graduate) and the effort will never be regretted.

But in case the advantage of a law school cannot be had, let the student select the best law office attainable for the commencement of his studies. And whenever possible, let him by all means, stipulate for not less than one hour in each week of instruction from the head of the office in reviewing the studies he has gone over. If need be, pay for such instruction over and above services rendered in the office. Under a competent instructor, the result will be found far more satisfactory than for the student to pursue his studies without assistance. In one case, in a small city where there were some half a dozen students preparing for the bar, they employed an instructor for one or sometimes two evenings a week at a reasonable price, and with satisfactory results. One cannot expect the best, or even good progress, studying without assistance in a law office. 
And in this connection, I cannot fail to urge the student not to be in haste to seek admission to the bar. Unfortunately, in some of the States the standard for admission is so low that with two years (and perhaps less) fairly diligent study, even in a private office, the student can pass the requisite examination. But do not be misled. What is apparently gained in time will prove an irreparable loss in all after life. His admission to the bar is the certificate of the court that he is entitled (and presumably qualified) to practice law. The tendency of this is, to cause the young lawyer to relax his diligence in 'study, whereas, whatever may have been his preparation, his legal studies have only commenced. The evil effects of the eager haste of Americans to enter early upon an active business life are more clearly shown in the profession of law than in any other. Scores of young lawyers of fair ability I have heard lament this mistake of their lives. They are doomed all their lives to a position of mediocrity when, had they devoted a year or two longer to a more thorough preparation, they might have achieved success in their profession. When they come in contact with others who enter the profession fully equipped, they at once become sensible of their deficiencies, become discouraged, and the battle for success is half lost in the beginning. The effect on a very few, possessed of indomitable energy and industry, may drive them to intense and successful efforts to overcome the disadvantage, but such cases are rare.

A most serious question, often disturbing the young lawyer upon admission, is the place he shall select for the practice of his profession. In many cases the question settles itself by considerations of birth, health, friends, etc. But in most cases probably the young man "has all the world before him where to choose," and the question becomes the more important from the fact that a mistake in its solution, may, if not fatal, at least cost some of the best years of his life. For removals from one place to another, except for urgent cause, are always to be avoided. Of course, there are cases where a man has built up a good reputation and practice in perhaps a village or small city, and in which it is evident business has reached its maximum, a change may be desirable to a larger field. And it thus happens that we see large cities more and more of late years absorbing the best professional talent of country places.

While it is almost impossible to lay down any rule of universal application on this point, yet it may be safely said in general, that if a lawyer would do a large business, he must go where business is, or where it is almost certain to be. In the latter case great 
caution and discrimination must be used, and even then chances must be taken. In all the newer States, villages which on a superficial view bid fair to become important cities, have after a few years reached their maximum growth. While it is manifestly impossible to lay down any rule by which one can surely determine the future of any new town, yet a careful study of its surroundings and natural advantages, coupled with the advice and experience of older men, will aid much in arriving at a correct conclusion. And where such conclusion proves correct, there are some advantages for the young lawyer in selecting such location, and growing up with it, rather than in a large city.

But, given exceptional, or at least full average, legal ability and preparation, ambition, tireless energy, physical vigor, and a willingness to bone down to hard work, to the sacrifice of pleasure, the large cities hold out the strongest inducements to the young lawyers in the long run. And that without regard to the question of whether he enjoys the advantage of friends and acquaintances to aid him, or the amount of competition he has to encounter. This statement is based, not only on my own experience as a young lawyer in New York city, but a somewhat widely extended observation in Western States. Of course the degree of success he may attain, will depend largely not only on the degree to which he may possess the qualities aforesaid, and others which might be named, but their practical application to the varying circumstances of his profession. And that success, whatever its measure, may not be attained as early in life as in a smaller place, but once gained, will go on increasing except for his own fault or misfortune. And here it may be stated, for the encouragement of the young lawyer, that wherever he locates, if he is fitted for his profession, has no bad habits, and attends to his business, he is at least assured of a competency. The exceptions to this are so rare as to be unworthy of mention.

The young lawyer in entering upon practice, must accustom himself to defeat, and to endure the same with equanimity. Experience alone, will enable him to apply his training and use his faculties to the most successful ends. The reasons of a court for making certain decisions are sometimes inscrutable and past finding out, and it is very unprofitable to quarrel with the court or lose one's temper over defeat. As an illustration of the curious reasons sometimes influencing a decision, I may refer to an instance in my own practice in a Territorial court more than forty years ago. At one term of the Supreme Court, I had four cases on the calendar for argument, and the opposing attorney was the 
same in all the cases. Two of the cases were pretty evenly balanced, and a decision might perhaps have been rendered either way without doing violence to the law,-one I expected to go against me, and the last I was perfectly sure of winning, as there was not an authority cited against me, and the opposing party had admitted the appeal was only taken for delay. In due time the first three of the cases were decided in my favor. Some time later, the last named was decided, and against me. There was no opinion filed in it. Meeting the Chief Justice sometime later I asked him the grounds on which the decision was rendered. $\mathrm{He}$ had forgotten the case, but I finally refreshed his memory. " $\mathrm{Oh}$ yes, the case of Brown v. Smith. Well, possibly that case might have been decided wrong, but we had decided all his other cases that term against Mr. N- (my opponent) and as this case did not seem of much importance, we thought might as well decide it in his favor."

Another case in illustration of the point may here be mentioned. A certain justice of the peace, whose knowledge of the law was extremely limited, was observed after the trial of a cause, and before rendering a decision, to visit a neighboring corn field, and spend some little time. This had occurred several times, and finally excited the curiosity of an attorney who had been unfortunate before him to ascertain the cause. After a trial in which he expected the visit would be repeated, he concealed himself near a well-trodden path, frequented by the magistrate, and had not long to wait for his appearance. Passing back and forth as in deep study, the justice at length drew a chip from his pocket, spat on it, and flipping it up said, "plaintiff wet, defendant dry." He picked it up - "defendant has it," and returned to render his decision.

It must not be inferred, however, from the foregoing that these are fair samples of the manner in which decisions were arrived at in Western courts in early days. They are cited rather for the encouragement of the young practitioner in his defeat, and to show that he is not necessarily in the wrong when a case is decided against him.

One point that cannot be too strongly urged upon the young lawyer in his start in life, is the danger of ruining his future (as a lawyer), is by engaging too early in life in politics. Such a course is almost always fatal to eminence in law. In middle or later life, when his professional reputation has been thoroughly established, he can better afford to follow his inclinations if, unfortunately, they should turn to politics. I say unfortunately, 
for at best their rewards are wholly unsatisfactory, and never pay what they cost. However successful in other fields, no higher reputation can ever be gained than that of an able and honest lawyer.

Another temptation to which every young lawyer will be exposed, and against yielding to which he cannot be too strongly urged, is that of temporarily using his client's money, which has come into his hands in his professional capacity. This has proved the ruin of not a few, who might otherwise have achieved success in their profession. Reference is not here made to attorneys who deliberately appropriate money of their client's without expectation, or even intention of returning it - such cases are rare. The young man is, or believes himself to be, in pressing need of money for a temporary purpose - he thinks he can easily replace the amount before it will be called for, and he yields to the temptation. He replaces the money, but if the practice is continued, he is inevitably caught sooner or later, by being unexpectedly called on for the money. He may be able to make it good, but he almost invariably loses that client, and very likely others whom he can influence. Make it a rule never to hold your client's money over night where it is possible to remit. You thus remove all temptation of misappropriating it, and secure a reputation for promptness and integrity, which will be invaluable in all future life.

Life is too short for a man even of extraordinary ability to become accomplished in all the branches of civil and criminal law. It is becoming the custom more and more in the legal profession, not less than in others, to make a specialty of some one general branch or department. This is wise, especially as applied to practice in the larger cities which afford business enough to sustain lawyers in different kinds of specialties. In country towns and villages, the attorney must usually accept all business that offers, and handle it as best he can; but in large cities, any one department, as real estate, insurance, commercial law, corporations, patent law, will be likely to give an attorney full employment, if he makes himself a thorough master of the branch which he selects. This end having been reached, the practice will be found less laborious and more satisfactory, than the attempt to practice in several departments, in some of which his legal knowledge must necessarily be more or less imperfect.

The science of pleading is one of the noblest studies which can engage the attention of the mind, even considered in the abstract, and without reference to its practical application, and as a mental 
discipline is perhaps not inferior to mathematics. It is to be feared that the New York Code (after which many of those in other States have patterned) does not tend to make skillful and accomplished pleaders. A system which starts out on the theory that pleading can be so simplified, that every man can be his own lawyer, must certainly fail of attaining that end. And it required but a few years' practice under the code to demonstrate the great advantage enjoyed by those who had mastered the science of pleading, as taught by Chitty, Gould and others of that rank in the profession. I know not to what extent these authorities are used as text-books at the present day, but am sure their careful study cannot fail to be of great benefit to one who would become an accomplished pleader, even under the loose system which has too largely obtained under the code.

But however skillful an attorney may become in pleading and practice, it must not be forgotten that these arts are only to be employed as means to an end - the arrival at truth in the controversy in hand. The reputation of the mere technical lawyer is not in itself a desirable one, and if such knowledge be used to obstruct the course of justice, it will prove a curse instead of a benefit. The young practitioner frequently errs in seeking to take advantage of his adversary's defects by demurrer or motion, unless, if sustained, they dispose of the action. He lays open to him the weak points of his case, and gives him time to proceed and strengthen them before the trial comes on. In most cases all the advantages to be gained by these proceedings can be equally gained by objections at the trial, where they would often prove fatal, while they might be remedied if taken at an earlier stage in the proceeding. It is well for the attorney to go directly to the merits of the case, and expend his energies on those, for if it is one of importance they will have to be reached in the end, and temporary successes in the early stages of the case, seldom pay what they cost. Of course there are cases where delay in a trial is an important element in ultimate success, and these will be treated accordingly.

The young lawyer must be cautioned, when a case is submitted to him, not to trust too readily and implicitly in the statements of his client in regard to his case. He may be honest, but he looks at it from his own standpoint, and self interest is a strong factor in biassing the judgment. Examine and cross-examine him closely on all the material points, and try to place yourself in the position of his adversary, and learn as far as possible the objections you will have to meet. Remember that in almost every 
important case there are two sides, while it often occurs that your client can see but one. Whenever the evidence is accessible, carefully examine, before advising your client on the merits of his case. You can better afford to lose a retainer, than to lose a suit for lack of the most thorough examination.

And this leads to the remark, that young lawyers in their anxiety to do business, frequently err in accepting cases in which there is no reasonable probability of success. The attorney may not often be in a position to choose his clients or cases, for the " human necessity of daily bread," may compel him to accept business sometimes which is not desirable. But this should be limited to the least possible amount-indeed, he had often better go hungry, than to accept cases where he is foredoomed to defeat, especially if of a disreputable class. Of course there are cases, which the lawyer must undertake in the discharge of his professional duty, and his sworn obligations to the court, without regard to prospects of success. But the reputation of losing more cases than he wins, is worse than that of having a small clientage. Better go slow and sure, rather than fast to ruin.

But after all these suggestions, even if heeded, can be of but minor aid to the young practitioner. Experience is and ever must be the great teacher, and wise is he who gives good heed to her lessons. Eternal vigilance and unwearied study must never be relaxed by those who would reach the highest rounds of the ladder which leads to legal fame. 